\title{
Historians and Their Information Sources
}

\section{Margaret Stieg Dalton and Laurie Charnigo}

This article reports on a survey of historians and a citation analysis undertaken to revisit the questions treated in Margaret F. Stieg's 1981 article published in College \& Research Libraries. It examines which materials historians consider to be the most important and how they discover them. Their attitudes toward and use of electronic materials were also studied. Many characteristics of historians' information needs and use have not changed in a generation: informal means of discovery like book reviews and browsing remain important, as does the need for comprehensive searches. Print continues to be the principal format. What has changed is that the advent of electronic resources has increased historians' use of catalogs and indexes in their efforts to identify appropriate primary and secondary sources of information.

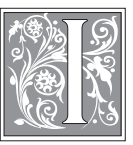

n 1750, Lord Chesterfield dismissed history as "only a confused heap of facts," unless there were maps and chronologies at hand to organize it; in 1980, the historian John Cannon assigned the sense-making role to the historian. To Cannon, the historian was "essentially a bringer of order to the past, a perceiver of patterns." What had taken place between those two statements was the evolution of a new craft-that of the professional historian. ${ }^{1}$

The business of the historian is to "research, analyze, and interpret the past," or as one historian has described it, "It's the collecting of data, it's the collating of data, it's thinking about it, piecing it together, trying to extract meaning from it and trying to establish patterns out of thousands of little scraps of information." ${ }^{2}$ In the course of their research, historians use sources of information that include "government and institutional records, newspapers and other periodicals, photographs, interviews, films, and unpublished manuscripts such as personal diaries and letters." These materials are the raw materials of research, the primary sources. To enrich analysis and interpretation, they seek secondary sources that are the writings of other historians and of scholars in other disciplines, especially in the social sciences, that offer theories and insights to illuminate the object of study. Evidence plus interpretation are the substance of historical study. ${ }^{3}$

It is no coincidence that historians have been prominent in the development of research libraries; Justin Winsor, librarian

Margaret Stieg Dalton is a Professor in the School of Library and Information Studies at the University of Alabama; e-mail: mdalton@slis.ua.edu. Laurie Charnigo is an Education Librarian in the Houston Cole Library at Jacksonville State University; e-mail: charnigo@jsucc.jsu.edu. 
of Harvard from 1877 to 1897 , is only the best known. As their interests expanded beyond political history to encompass economic, social, and cultural interests, from concentration on leaders to include ordinary citizens of every race, color, creed, and gender, and from the United States and Western Europe to the entire globe, historians pressed consistently for ever more comprehensive research collections. The redefinition of acceptable sources to legitimize those that present popular culture expanded their information needs still further. Diffuse (some exasperated collection development officers would add insatiable) is the only adequate description of the information needs of historians. ${ }^{4}$

This study, a sequel to the study published in 1981 by Margaret F. Stieg on the information needs of historians, examines the information sources used by historians to identify material for both research and teaching. ${ }^{5}$ It addresses the sources historians consider important, how they locate them, and what their preferences and priorities are. Particular attention is paid to the role of electronic resources. A transformation in how information is delivered to scholars has taken place in the past twenty years, and the information available has changed in both character and quantity. How have the practices of historians changed?

At the beginning of March 2003, a sixpage survey, accompanied by a personal letter, was sent to a random sample of 986 historians chosen from history departments of universities in the United States classified by the Carnegie Classification of Institutions of Higher Education as doctoral/research universities - extensive (see Appendix A). The survey also was available online. Three weeks after the initial mailing, an e-mail that included the link to the online survey was sent in the hope of increasing response. A total of
278 (27\%) usable surveys were returned, of which $184(66 \%)$ were by mail and 94 (33\%) were online. In October 2003, a follow-up survey of seven open-ended questions was sent to sixty-six respondents to the March survey who had expressed their willingness to be contacted if the authors had further questions (see Appendix B). Exactly half of the sixty-six responded; many thoughtful, insightful answers were obtained.

"Information sources" is a term that means different things to different people. Librarians usually use it to signify the bridges that get scholars to the sources of the primary and secondary material they need for research, whether those bridges are in print, electronic, or human form. Historians sometimes use the term in the same sense but also may use it to mean the primary and secondary material that is the raw material of their research. The format of the survey was designed to accommodate both interpretations, and the results reflect this definitional variation.

To obtain complementary information, citations in books and articles were analyzed. Because what people do often fails to match what they say - a behavior pattern to which historians were considered unlikely to be an exception-perception and reality can be two different things. If, for example, historians assert that audiovisual materials are very important to their work but never cite them, the contrast has to raise doubts about the value of the assertion. Two separate sets of data were created, one based on fifty citations randomly selected from each of five books and five journals clustered around the year 2001 and the other selected from five books and five journals clustered around 1975. The books selected for analysis were chosen from among those awarded prizes by the American Historical Association on the assumption that these 
books represented the profession's idea of excellence. The five journals were those journals of historical scholarship that had the highest impact factor in the ISI rankings. Each data set included the author, brief title, date of publication, language, type of publication, and LC number of every bibliographic reference in the citations. ${ }^{6}$

\section{The Literature of Information Seeking}

At the time of the Stieg study on the information needs of historians, studies of information behavior were relatively infrequent. They have since become so common that they are now a "flood." Donald Case estimates the number of publications on the subject of information behavior at more than ten thousand in the 1990s alone. This literature can be categorized into studies that look at the use of channels and sources of information, studies of the seeking of information and the encounter with information by the individual, and studies of the interpretation and meaning that individuals derive from information. It can be divided on the basis of the population studied, the research method employed, and the type of information sought. In addition, the corpus includes efforts to develop models, theories, and paradigms of information behavior. $^{7}$

Studies that take historians as their population and that emphasize how and why they seek the information they do include those of Peter Hernon, Donald O. Case (1991), Charles Cole, Roberto Delgadillo and Beverly P. Lynch, Rebecca Green, and Wendy M. Duff and Catherine A. Johnson. Case's study described how twenty American historians chose their research topics and how they progressed as they sought information in libraries and archives, recorded and organized their findings, and wrote about their subjects. Cole studied the cognitive activity of forty-five Ph.D. history students in relation to information events. Delgadillo and Lynch also studied history graduate students, paying particular attention to the similarities and differences between their information-seeking behavior and that of established scholars. Duff and Johnson's focus was on the search for information within archives and Hernon's on the use of government publications by historians. Green's article attempted to test the effectiveness of following up citations in footnotes by generating twelve questions in the humanities, four of which had some historical element, and then comparing attempts to identify seed documents by searching bibliographic sources and using footnotes. ${ }^{8}$

Pertinent studies that emphasize what historians do rather than the how and why can be divided into those that, like Stieg's 1981 study, look at information use by individual scholars broadly and those that focus on a particular aspect or type of information use. In only a few cases is the population in these "what" studies limited to historians; more frequently, historians are one of the groups of scholars in studies that look at the information patterns of social scientists and/or humanists. ${ }^{9}$ Such studies include the pioneering work done at Bath University under the leadership of Maurice Line on the information needs of social scientists, work that included some areas of history, and the Sheffield studies of the information needs of humanists, which included historians. Susan S. Guest studied the use of bibliographic tools by humanities faculty members at SUNY Albany and Rebecca Watson-Boone summarized the picture of the humanist as of the mid1990s. Constance C. Gould's assessment, based on interviews with scholars in the humanities, is a straightforward summary of the types of sources need by historians. A recent study by the Digital Library 
Federation, the Council on Library and Information Resources, and Outsell, Inc., gives a detailed statistical picture of the use of libraries and information sources by faculty and graduate students in all fields. Only broad categories such as social sciences and biological sciences, however, are analyzed, not individual disciplines. Many questions in this DLF/ CLIR/Outsell study relate to electronic formats. ${ }^{10}$ By limiting its scope to historians, the current study will be able to give a more detailed picture of the information behavior patterns that prevail in the practice of historical scholarship and fill in some of the outlines that have emerged from broader studies.

Research also has been conducted to distinguish among the different stages of information-seeking behavior, a focus that often incorporates not only the how and why, but also the what. In an early study of this kind, Peter A. Uva identified five stages of historians' research: problem selection, detailed planning, data collection, analysis and interpretation, and writing/ rewriting, and, in general terms, the types of information used at each stage. Uva pointed out that historians tend to work at the different stages simultaneously; one historian quoted by Barbara C. Orbach considered that "all stages are potentially present all the time to some degree." Case's 1991 study of American historians was influenced by Uva's work. Other articles that look at the stages of information include David Ellis's model of the informationseeking patterns of academic researchers and Clara M. Chu's study of literary critics. Another article of interest is the modification of Ellis's model by Helen R. Tibbo and Lokman I. Meho. ${ }^{11}$

A work of particular relevance to the present study is Tibbo's Abstracting, Information Retrieval and the Humanities. Her goal was to identify ways in which indexing and abstracting in history could be improved, and in pursuit of this purpose, she addressed many of the same topics that this study does. She discussed the nature of history and examined the information-seeking behavior of historians. Her conclusions were based on in-depth interviews conducted with twenty-five historians at the University of Maryland, College Park, in the fall 1988 semester. ${ }^{12}$

Citation studies, beginning with the dissertation done by Arthur Monroe McAnally at the University of Chicago in 1951 on the materials used in the study of U.S. history, look at information sources used by historians in a different way. The 1972 article by Clyve Jones, Michael Chapman, and Pamela Carr Woods was based on an analysis of seven thousand references drawn from a sample of articles on English history. Studies of citations in individual journals are common: the American Historical Review, the Journal of American History, the Tennessee Historical Quarterly, Technology and Culture, and the Journal of Garden History are among those that have been analyzed. ${ }^{13}$

In any study of information-seeking behavior done in the past fifteen years, digital information has been at least an element, and many studies center on some aspect of technology. Older work (more than ten years old) is mainly of historical interest at this point, showing how far and how fast scholars in the humanities have come. Recent writing has tended to focus on the Web. Two groups of studies are of particular interest. Stephen Wiberley and William Goodrich Jones looked at the information-seeking patterns of humanists in 1989, in 1994, and again in 2000 to give an excellent picture of evolving behavior. The Getty project studied the use of DIALOG databases in 1988-1990 by scholars in the humanities in great detail. ${ }^{14}$

Most recently, articles that look at electronic publishing have begun to appear. 
A 1999 survey of Canadian faculty in the social sciences and humanities gives detailed information on their use of and attitudes toward electronic publishing. Suzanne Graham analyzed citations in the American Historical Review and the Journal of American History with particular attention to electronic sources. Articles on electronic information sources, most of which are primarily informative and descriptive rather than analytical, have begun to appear in mainstream historical journals. Their presence indicates a new stage of information awareness and concern among historians. ${ }^{15}$

The considerable body of research has established the features of humanistic research. Sue Stone's 1982 description is the standard:

- Humanists tend to work alone.

- Humanists need to browse.

- Humanists use a variety of approaches to their materials, often borrowing methods associated with disciplines other than their own.

- Humanists need a wide range of primary materials, but books and journals are the most frequently used formats.

To this picture of humanistic research, Ron Blazek and Elizabeth Aversa add the importance of questions of value and the centrality of the library. Subsequent research has amplified these features, such as Wiberley's point that respect for influential peers also was characteristics of humanists, but the basic model remains intact. This model is an accurate description of historians' practices and a foundation on which to build. ${ }^{16}$

\section{The Historians}

The 278 historians who completed the survey tended to be senior faculty and older faculty; over half were full professors and 41 percent had more than twenty-six years of teaching experience at the postsecondary level. Two-thirds were male, one-third female. The way the respondents chose to describe themselves tells much about the character of historical scholarship. The vast majority (86\%) used a geographical term. American historians were the single largest group (38\%), followed by European (29\%), Latin American/French West Indies (7\%), and Asian (7\%). Only 56 percent of the historians described themselves with a chronological limitation, but 82 percent selected a topical category. Chronologically, their interests are predominantly in the modern or early modern period. Topically, the most common labels chosen were social history (19 historians), women's history (13), and cultural history (10). Nine individuals each chose religious, scientific, and legal history; and six individuals each chose political, medical, intellectual, and foreign policy/foreign relations. These patterns confirm the prominence of newer areas, such as social and cultural history, as well as the increasing fractionation of the field because many historians felt that more than one category was necessary to describe themselves. Twenty-five years ago, history was an umbrella term; the passage of time has only made it a more capacious umbrella. ${ }^{17}$

\section{The Sources}

The results of the request to please check all sources of information considered important to research are presented in table 1 .

The question closest to this in the Stieg survey asked historians to identify their most frequently used sources. The rank order of the first three types of sources was identical: books, journals, and manuscripts ranked first, second, and third in both. In the years since the Stieg study, dissertations appear to have increased in perception of utility, newspapers have slipped slightly, and government documents remain the same. Because other for- 


\begin{tabular}{|l|c|c|}
\hline \multicolumn{3}{|c|}{$\begin{array}{c}\text { TABLE 1 } \\
\text { Materials Considered Important for } \\
\text { Research }\end{array}$} \\
\hline \hline Materials & Total & Percentage \\
\hline Books & 274 & $99 \%$ \\
\hline Journal articles & 273 & $98 \%$ \\
\hline $\begin{array}{l}\text { Manuscripts, archives, } \\
\text { and special collections }\end{array}$ & 262 & $94 \%$ \\
\hline Dissertations & 241 & $87 \%$ \\
\hline Newspapers & 201 & $72 \%$ \\
\hline Government documents & 187 & $67 \%$ \\
\hline Photographs & 172 & $62 \%$ \\
\hline Maps & 169 & $61 \%$ \\
\hline $\begin{array}{l}\text { Publications of scholarly } \\
\text { organizations }\end{array}$ & 167 & $60 \%$ \\
\hline Web sites & 162 & $58 \%$ \\
\hline Conference proceedings & 150 & $54 \%$ \\
\hline Oral interviews & 121 & $44 \%$ \\
\hline Statistical sources & 116 & $42 \%$ \\
\hline Audiovisual materials & 107 & $38 \%$ \\
\hline $\begin{array}{l}\text { Artifacts or museum } \\
\text { pieces }\end{array}$ & 83 & $30 \%$ \\
\hline Genealogical sources & 65 & $23 \%$ \\
\hline
\end{tabular}

tions, books, newspapers, government documents, journal articles, oral interviews, photographs or images, artifacts or museum pieces, published primary documents, statistical sources, and audiovisual materials. Those used by ten or more for secondary information were books, journal articles, dissertations, and Web sites. The incorporation of nonprint materials into their research, and the emergence of digital information is apparent. (Web sites were cited as a source of primary information by seven historians.)

Citation analysis amplifies this picture based on historians' perceptions. In the citation analysis of 2001 materials, books ranked first in terms of frequency of citation, manuscripts second, and journal articles third. Government documents were the next most-used category, followed by newspapers. All other categories were minuscule, far smaller than would have been predicted from the survey responses on the question of

mats included in the two surveys differed somewhat, direct comparisons between them are not possible. What does appear clear, however, is that historians are more open to information sources beyond the traditional printed sources than they were a generation ago. In the present survey audiovisual materials were considered important to their research by 38 percent of the respondents.

When historians in the present survey were asked to distinguish between the materials they used most frequently for primary information and those they used most frequently for secondary information, a more differentiated picture emerged. Sources used most frequently for primary information by ten or more historians were, in descending order, archives, manuscripts and special collec- importance.

Among citations to primary sources, primary printed sources were more numerous than manuscript sources, a somewhat surprising statistic in view of the close identification of primary sources with manuscripts in the perception of historians. In the category of secondary information, books and articles were overwhelmingly the leading sources. When looking only at secondary information, books at 82 percent were perceived in the survey as somewhat more important sources of information than articles at 70 percent. The figures in the 2001 citation analysis suggest a larger discrepancy; 75.9 percent of the secondary citations were to books, 18.3 percent to articles. ${ }^{18}$ Similar ratios of books to journals are found 


\begin{tabular}{|l|c|c|c|r|r|c|}
\hline \multicolumn{7}{|c|}{ TABLE 2 } \\
\hline & $\mathbf{1 9 7 5}$ & \% Total & \% Secondary & $\mathbf{2 0 0 1}$ & \% Total & \% Secondary \\
\hline \hline Books & 259 & 26.0 & 84.0 & 376 & 34.7 & 73.1 \\
\hline Articles & 36 & 3.6 & 11.7 & 91 & 8.4 & 17.7 \\
\hline Chapters in books & 13 & 1.3 & 4.2 & 47 & 4.3 & 9.1 \\
\hline Total secondary & 308 & 34.9 & & 514 & 47.4 & \\
\hline Total citations & 995 & & & 1,083 & & \\
\hline
\end{tabular}

in other citation studies, regardless of the dates of the publications that were analyzed. ${ }^{19}$

Is the balance between books and articles changing? There have been suggestions that the importance of articles has been increasing and, if importance is defined as frequency of use, the citation data provide support for this perception. ${ }^{20}$ As shown in table 2 , in 1975, articles were 3.6 percent of the total citations and 11.7 percent of the citations to secondary information. In 2001, they were 8.4 percent of the total citations and 17.7 percent of the secondary citations. When the secondary material that appeared as a chapter in a book is factored in, the growth in the citation of article-length publications is even greater. Chapters in books were 1.3 percent of the total 1975 citations and 4.2 percent of the secondary citations; the 2001 figures were 4.3 percent of the total citations and 9.1 percent of the secondary citations.

\begin{tabular}{|l|c|c|c|c|}
\hline \multicolumn{5}{|c|}{$\begin{array}{c}\text { TABLE 3 } \\
\text { Importance of Secondary Literature According } \\
\text { to Age of Historian }\end{array}$} \\
\hline \hline Age & $\begin{array}{c}\text { Total } \\
\text { Responses }\end{array}$ & $\begin{array}{c}\text { Equally } \\
\text { Important }\end{array}$ & $\begin{array}{c}\text { More } \\
\text { Important }\end{array}$ & $\begin{array}{c}\text { Less } \\
\text { Important }\end{array}$ \\
\hline $30-39$ & 57 & $81 \%$ & $14 \%$ & $5 \%$ \\
\hline $40-49$ & 50 & $72 \%$ & $18 \%$ & $10 \%$ \\
\hline $50-59$ & 75 & $76 \%$ & $21 \%$ & $3 \%$ \\
\hline $60-69$ & 64 & $62 \%$ & $22 \%$ & $16 \%$ \\
\hline $70+$ & 11 & $64 \%$ & $27 \%$ & $9 \%$ \\
\hline
\end{tabular}

Although the extent of this shift in balance should not be overstated, a trend does appear to be emerging. One factor that favors the production of articles is an increased importance of currency in historical research. ${ }^{21}$ Books have an essential role in providing context, but articles do the same thing (if less comprehensively) and do it faster. As every author of a book knows, it takes a lot longer to write a book and get it published than it does to bring an article to the light of day. A second factor favoring articles is ease of publication, a factor that has nothing to do with intellectual considerations. In a pattern going back a century, scholars have created periodicals in ever-morespecialized areas to meet their need to publish; the proliferation of journals is a cliché of library literature. ${ }^{22}$ Scholarly book publishing, on the other hand, is disadvantaged by a confluence of economic factors, the most important being the considerable reduction in what academic libraries spend on books. The priorities of the historians, most of whom are employed by universities, also are a factor. Publication expectations for tenure have risen steadily, and many universities have instituted some kind of posttenure review. Given these constraints, writing 
articles rather than books is a rational choice: an article requires a much smaller investment. If an article is rejected, less has been lost than if a book manuscript has been rejected. In addition, the citation of an article takes up the same amount of space on a résumés list of publications as a book, enhancing the impression of quantity, that American shibboleth. ${ }^{23}$

A real shift, and one of some significance, also has occurred in the relationship between primary and secondary information. As Nicholas J. Morgan and Richard H. Trainor noted, generalizations about the past have become more important. The presence or absence of citations to significant previous scholarship in a historical study is a basis for judging its value. In Tibbo's study, all the historians she interviewed considered the citation of previous scholarship important, 68 percent considered it essential. To the question in the present study of whether historians felt that secondary literature was more important, less important, or equally important as it had been when they received their doctorates, the older the historian, the more likely the response was to be more important (table 3). ${ }^{24}$

Evidence from citation analysis confirms that the importance of secondary literature (importance again being defined as frequency of use) has been increasing. In the analysis of 2001 prize-winning books and high-impact journals, 47.4 percent of the citations analyzed were to secondary material, whereas in the 1975 analysis, the percentage of secondary material was only 34.9 percent. Growth in the raw number of citations suggests the same thing, although without analysis of every citation one cannot achieve certainty. Those figures were an average of 1,108 citations per book in 2001 versus 1,020 per book in 1975 and an average of 97 citations per article in 2001, as compared with 66 citations per article in 1975. Within a citation there was also greater density. Five hundred citations in 1975 materials produced 995 references; the same number of citations in 2001 produced 1,083 references. M. Sara Lowe observed the same growth in numbers in her citation analysis of the American Historical Review. ${ }^{25}$ This growth probably can be attributed partly to the simple fact that, thanks to

\begin{tabular}{|l|c|c|}
\multicolumn{3}{|c|}{ mary Information } \\
\hline \hline Method of Discovery & Total & Percentage \\
\hline Finding aids & 64 & $26 \%$ \\
\hline Footnotes & 50 & $20 \%$ \\
\hline Archival/library catalogs & 49 & $20 \%$ \\
\hline In the archives & 47 & $19 \%$ \\
\hline Bibliographies & 28 & $11 \%$ \\
\hline Bibliographic databases & 19 & $8 \%$ \\
\hline $\begin{array}{l}\text { Conversations with other } \\
\text { historians }\end{array}$ & 12 & $5 \%$ \\
\hline Archivists & 10 & $4 \%$ \\
\hline Web sites & 7 & $3 \%$ \\
\hline Reference librarians & 6 & $2 \%$ \\
\hline Archival research & 5 & $2 \%$ \\
\hline Specialized bibliographies & 5 & $2 \%$ \\
\hline Legal citations & 4 & $2 \%$ \\
\hline Oral interviews & 4 & $2 \%$ \\
\hline Consulting experts & 3 & $1 \%$ \\
\hline Newspapers & 3 & $1 \%$ \\
\hline Government indexes & 3 & $1 \%$ \\
\hline Library & 2 & $1 \%$ \\
\hline Reviews & 1 & $0 \%$ \\
\hline Amateur historians & 1 & $0 \%$ \\
\hline Local history offices & 1 & $0 \%$ \\
\hline While reading other sources & 1 & $0 \%$ \\
\hline
\end{tabular}


the steadily increasing pressures to publish, more literature is produced relevant to any given topic and partly to the advancing dominance of the scientific model in American academic life. Moreover, this growth makes it more difficult than it already was for academic historians to pretend that they write for Everyman - an ambition of historians in the formative years of the discipline-because Everyman is allergic to footnotes and what they represent. ${ }^{26}$

Historians perceive themselves as using microfilm; almost twothirds said they used it sometimes. "Infrequently" is probably more accurate. Of the 1,080 references of 2001 books and articles analyzed, only two were to microfilm. (Microfilm was not used as a category in the analysis by format; the reference was, instead, categorized by its original format [e.g., manuscript]. However, when an item was used in microform, that fact was noted and those notes enabled the above statement to be made.) Microfilm does not seem to have become more liked in the years since the Stieg study; one historian tried to use it "as little as humanly possible. It gives me migraines."

\section{Discovering Information}

Because of the great dispersion of potentially useful material, historians face a particularly challenging problem that they solve with an assortment of approaches. When asked how they found information, more tended to check book reviews than any other alternative. When asked how they located primary material, the four most frequently used methods were, in order, finding aids, footnotes, and references in

\section{TABLE 5}

Most Frequent Way of Discovering Secondary Information

\begin{tabular}{|l|c|c|}
\hline \hline Method of Discovery & Total & Percentage \\
\hline Bibliographic databases & 57 & $23 \%$ \\
\hline Reading other sources & 54 & $21 \%$ \\
\hline $\begin{array}{l}\text { Footnotes, references, notes, } \\
\text { and bibliographies in other } \\
\text { works }\end{array}$ & 54 & $21 \%$ \\
\hline Library catalogs & 47 & $19 \%$ \\
\hline Bibliographies (unspecified) & 38 & $15 \%$ \\
\hline $\begin{array}{l}\text { Book reviews, new books, } \\
\text { \& journal listings }\end{array}$ & 34 & $13 \%$ \\
\hline Specialized bibliographies & 10 & $4 \%$ \\
\hline $\begin{array}{l}\text { Colleagues, academic } \\
\text { experts }\end{array}$ & 9 & $4 \%$ \\
\hline Browsing the library stacks & 7 & $3 \%$ \\
\hline Publisher catalogs & 7 & $3 \%$ \\
\hline Using the library & 5 & $2 \%$ \\
\hline Librarians & 5 & $2 \%$ \\
\hline $\begin{array}{l}\text { Conference publications \& } \\
\text { participation at conferences }\end{array}$ & 4 & $2 \%$ \\
\hline By accident & 3 & $2 \%$ \\
\hline Dissertations & 3 & $2 \%$ \\
\hline Archival-finding aids & 2 & $1 \%$ \\
\hline World of mouth & 2 & $1 \%$ \\
\hline General reference works & 1 & $0 \%$ \\
\hline Online discussion lists & 1 & $0 \%$ \\
\hline Hunches & 1 & $0 \%$ \\
\hline Commercial bookstores & 1 & $0 \%$ \\
\hline Personal knowledge & 1 & $0 \%$ \\
\hline Local historians & 1 & $0 \%$ \\
\hline Friends & 1 & $0 \%$ \\
\hline
\end{tabular}

other sources, archival and library catalogs, and during research in a collection. (See table 4.) For secondary information, the four most frequent ways were using bibliographic databases, reading other sources, footnotes, references, and bibliographies in other works, and library catalogs. (See table 5.) Only a very few 
historians identified colleagues or librarians as their most frequently used method of finding relevant information, whether primary or secondary information, although colleagues and other historians were considered slightly more useful than librarians.

Systematic bibliographic searches in databases, use of other sources such as aids designed to disseminate information about resources, and careful, patient, wide reading followed by pursuit of leads resulting from the reading are clearly the foundation of historical research; the package was summarized by one historian as "diligence." The methods used have not changed in a generation, but the relative frequencies have. In the Stieg survey, the five most common ways of discovering published information were, in descending order, bibliographies or references in books or journals, specialized bibliographies, book reviews, library catalogs, and abstracts or indexes. When these results are compared with table 5,

\begin{tabular}{|c|c|c|}
\hline \multicolumn{3}{|c|}{$\begin{array}{c}\text { TABLE } 6 \\
\text { Most Frequently Used Indexes, } \\
\text { Abstracting Services, and Specialized } \\
\text { Bibliographies }\end{array}$} \\
\hline Title of Source & Total & Percentage \\
\hline $\begin{array}{l}\text { America, History and } \\
\text { Life (ABC-CLIO) }\end{array}$ & 40 & $20 \%$ \\
\hline $\begin{array}{l}\text { Historical Abstracts } \\
(\mathrm{ABC}-\mathrm{CLIO})\end{array}$ & 37 & $18 \%$ \\
\hline WorldCat (OCLC) & 31 & $15 \%$ \\
\hline JSTOR & 19 & $9 \%$ \\
\hline $\begin{array}{l}\text { International Medieval } \\
\text { Bibliography (IMB) }\end{array}$ & 9 & $4 \%$ \\
\hline Various Library Catalogs & 7 & $4 \%$ \\
\hline $\begin{array}{l}\text { Isis Current Bibliography } \\
\text { of the History of Science }\end{array}$ & 6 & $3 \%$ \\
\hline $\begin{array}{l}\text { Academic Search Elite } \\
\text { (EBSCOhost) }\end{array}$ & 6 & $3 \%$ \\
\hline Project Muse & 5 & $3 \%$ \\
\hline L'Année philologique & 5 & $3 \%$ \\
\hline
\end{tabular}

it is clear that, as Tibbo predicted, historians are making greater use of formal bibliographic tools and relying less on their own bibliographic knowledge, book reviews, browsing, and colleagues. ${ }^{27}$

Historians showed considerably greater knowledge of indexes and abstracts than they did in the Stieg study. The Stieg survey offered respondents a selection of commonly used titles to check, with an option of adding more titles; the results made it apparent that many historians checked titles they thought they ought to be using or those with names they recognized. The Reader's Guide, that staple of school library instruction, was the single most frequently checked index. In the present survey, no checklist was offered so that if a respondent named a title, it is probable that it really was one on which he or she depended. The top ten results to the question which indexes, abstracting services, specialized, or history-related bibliographies they used most often are presented in table 6 .

These indexes, abstracting services, and bibliographies are a mixture of broad multidisciplinary, general historical, interdisciplinary, and specialized resources, all of which meet some aspect of the needs of historians. America, History and Life, and Historical Abstracts were designed specifically for historians; they abstract books as well as a wide range of historical journals and historical articles from journals in other fields. Sources of greater disciplinary breadth are JSTOR and ProjectMuse, which both give access to large back files of scholarly articles in many disciplines, although they are not normally considered indexes. WorldCat is the single largest listing of book material in the world and offers not only subject access, but also keyword access, a feature essential 
in a field where vocabulary control is problematic. Not only in this question, but throughout the survey, respondents expressed appreciation of WorldCat. As one individual stated, "WorldCat rules!" The specialized bibliographies in table 6 differ from the twenty-five others named by respondents only in that they were named often enough to make the cutoff point of three percent.

History is often referred to as an interdisciplinary discipline and the sources in table 6 confirm the validity of the description. Moreover, it is a description that accords with the results of the citation analysis. Secondary material cited ranged literally from A to Z in the Library of Congress classification scheme. In addition to the D, E, and F categories for history, cited material came from, among others, the categories applied to philosophy, psychology, anthropology, economics, sociology, political science, education, art, language and literature, science, agriculture, technology, and military and naval science. ${ }^{28}$ The breadth of the discipline of history is both cause and effect of the information sources used by its practitioners. The absence of highly specialized indexes from nonhistorical fields indicates the limits of that breadth.

Additional comments on the survey questions about how information is discovered reinforced the data given in the tables and sometimes extended the data. Many historians emphasized the importance of following footnote and reference trails from other research. One wrote in capitals, "THE KEY." ${ }^{29}$ The value of the human element also was affirmed; friends and acquaintances, collectors, participants in contemporary history, amateur historians, and the nonprofessional staff in archives were mentioned specifically as useful sources.

One follow-up question asked the historians whether quality, availability, or ease of use most affected their choice of an information source. Most reported that quality was the most important consideration, although several made the worthwhile point that quality was of little relevance if the source was unavailable. The historians, however, did seem willing to exert themselves to obtain what they regarded as necessary. They defined quality in a bibliographic source principally in terms of coverage; accuracy and organization also were concerns.

Serendipity, when the meaning of the word is extended beyond the dictionary's definition as the gift of finding something valuable that was not sought to include the finding of something not known, but hoped for, plays a significant role in historical research. Browsing is an invitation to opportunity and was a frequent method of choice. Browsing usually meant scanning library shelves in an area that was a logical, but not guaranteed, location of information; but sometimes the browsing was electronic, a practice called "keyword spelunking" by one historian. ${ }^{30}$ Few of the survey respondents could recall a specific occasion, but many testified to its value. One historian did recall an occasion when a book's cover induced him to pick up the book. The book turned out to be a listing of the personal library of an individual about whom he was writing a paper. Considerably later, the historian realized the opportunities such a source provided and used it to prove his hypothesis. Serendipity may not happen often, but when it does, it is likely to turn up something of major importance. ${ }^{31}$

\section{Electronic Sources}

Although earlier writers could say that the use of electronic sources by humanists was limited, the combination of easy access and databases that truly serve the needs of humanists has changed that. ${ }^{32}$ The catalogs of many research libraries 
were already available, but in the past five years networked databases, usually with remote access, have become the norm in academic libraries. These databases include not only digital versions of indexing and abstracting services, but also a host of products such as JSTOR, Early English Books Online, Accessible Archives, and North American Women's Letters and Diaries. ${ }^{33}$ Most of the historians in this survey used electronic sources readily, although 16 percent, or one in six, indicated that they used electronic databases rarely or never.

The responses to a question to name the electronic databases most frequently used were very similar to the sources most frequently used to discover secondary information. (See table 7.) Most historians depended primarily on the library of their own institution for the delivery of these electronic databases.

Comprehensiveness is clearly the highest priority in searching a database. When asked whether they preferred

TABLE 8

When a Search Yields Too Many Hits...

\begin{tabular}{|l|c|c|}
\hline \hline & Total & Percentage \\
\hline $\begin{array}{l}\text { I think of new terminology to use } \\
\text { in my search. }\end{array}$ & 158 & $57 \%$ \\
\hline $\begin{array}{l}\text { I go through all records retrieved } \\
\text { not wanting any citations to fall } \\
\text { through the cracks. }\end{array}$ & 93 & $33 \%$ \\
\hline $\begin{array}{l}\text { I try to choose those citations from } \\
\text { the most respected journals in the } \\
\text { profession. }\end{array}$ & 59 & $21 \%$ \\
\hline I choose the most current citations. & 50 & $18 \%$ \\
\hline \begin{tabular}{l} 
I start over. \\
\hline $\begin{array}{l}\text { I ask a librarian to show me how } \\
\text { to perform an effective search in } \\
\text { that particular database. }\end{array}$
\end{tabular} & 28 & $18 \%$ \\
\hline $\begin{array}{l}\text { I look for another database from } \\
\text { which to do the same search. }\end{array}$ & 19 & $7 \%$ \\
\hline
\end{tabular}

TABLE 7

Most Frequently Used Electronic Databases

\begin{tabular}{|l|c|c|}
\hline \hline Database Title & Total & Percentage \\
\hline $\begin{array}{l}\text { America, History and Life } \\
\text { (ABC-CLIO) }\end{array}$ & 59 & $28 \%$ \\
\hline JSTOR & 51 & $24 \%$ \\
\hline WorldCat (OCLC) & 37 & $18 \%$ \\
\hline Project Muse & 30 & $14 \%$ \\
\hline None & 25 & $12 \%$ \\
\hline $\begin{array}{l}\text { Historical Abstracts } \\
\text { (ABC-CLIO) }\end{array}$ & 22 & $10 \%$ \\
\hline Library Catalogs & 9 & $4 \%$ \\
\hline Rarely Use Them & 8 & $4 \%$ \\
\hline LexisNexis & 8 & $4 \%$ \\
\hline History Cooperative & 7 & $4 \%$ \\
\hline $\begin{array}{l}\text { Expanded Academic } \\
\text { ASAP (InfoTrac) }\end{array}$ & 7 & $4 \%$ \\
\hline ITER Bibliography & 6 & $3 \%$ \\
\hline ProQuest & 6 & $3 \%$ \\
\hline $\begin{array}{l}\text { Early English Books } \\
\text { Online-EEBO }\end{array}$ & 5 & $2 \%$ \\
\hline
\end{tabular}

depth, described as "retrieval of the largest number of records which might pertain to my topic and in which I must spend time filtering out irrelevant citations," or relevance, defined as "retrieval of a few records, all of them relevant to my topic, but with the chance that many other works might fall through the cracks, due to the limiting parameters of this type of search," 70 percent of the respondents chose depth. Historians would seem to disagree with Hernon's assertion that the assumption that more information is better is false. ${ }^{34}$

Although actual searches would need to be analyzed to 
obtain precise information about search strategies in electronic databases, the survey did yield some information on the topic. For the historians in the survey, subject searching tends to mean keyword searching rather than subject headings or descriptors, an approach suited to the event, person, and topically oriented character of historical writing. ${ }^{35}$ And when their searches produce "too many hits," they report that they proceed in the ways shown in table 8 .

The problems they experienced with electronic sources were primarily with the scope and indexing of the source, secondarily related to equipment or software. One third of the complaints related to scope: sources did not include needed information or resources; sources did not cover the dates needed; sources were not international enough, or as some put it, too anglophone; sources did not offer full text. Another third were dissatisfied with the indexing terminology or indexing in general. Problems identified that related to equipment or software included poor search engines, slow response time, difficulty in navigation, and frequent format or interface changes. Remaining problems do not fit into any particular category. The most frequently mentioned was simple lack of access to needed databases. (See table 9.) Absence of international standards also was mentioned, and a few historians acknowledged that the fundamental problem was their own lack of knowledge.
Historians find electronic sources more helpful in locating secondary information than in locating primary materials. In the survey, 90 percent described them as very helpful or sometimes helpful in locating secondary information; only 61 percent used the same terms with relation to primary information. Those preferring the electronic format in indexes outnumbered by two to one those preferring the print format; almost a third are indifferent. Preference was age related; the older the historian, the likelier he or she was to prefer print.

Almost two-thirds (64\%) used the Internet from home, and responses to the question about which Web sites were

\begin{tabular}{|l|c|c|}
\hline \multicolumn{3}{|c|}{ TABLE 9 } \\
\hline Problems Encountered Using Databases \\
\hline Problems & Total & Percentage \\
\hline What they exclude & 17 & $18 \%$ \\
\hline Terminology & 13 & $13 \%$ \\
\hline Too many hits, irrelevant citations & 13 & $13 \%$ \\
\hline Poor search engines/options & 11 & $11 \%$ \\
\hline Too slow & 10 & $10 \%$ \\
\hline Hard to operate/navigate & 9 & $9 \%$ \\
\hline Access problems & 7 & $7 \%$ \\
\hline Does not include needed dates & 7 & $7 \%$ \\
\hline Poor indexing & 7 & $7 \%$ \\
\hline Technical problems & 6 & $6 \%$ \\
\hline No consistency among databases & 5 & $5 \%$ \\
\hline Not international enough in scope & 5 & $5 \%$ \\
\hline Personal lack of knowledge & 4 & $4 \%$ \\
\hline Not full text & 3 & $3 \%$ \\
\hline Too many format/interface changes & 2 & $2 \%$ \\
\hline Multidisciplinary nature of the field & 2 & $2 \%$ \\
\hline Ergonomically uncomfortable & 1 & $1 \%$ \\
\hline Errors & 1 & $1 \%$ \\
\hline Lack of browsability & 1 & $1 \%$ \\
\hline Cost & 1 & $1 \%$ \\
\hline Discrepancy between those who \\
make them and those who use them & 1 & $1 \%$ \\
\hline & & \\
\hline
\end{tabular}


most often visited showed considerable familiarity with the range of possibilities. Among the leaders were Web sites that offer the possibility of information about or acquisition of information sources, such as the online catalogs of libraries or the site of a bookseller. Web sites affiliated with scholarly institutions were popular. The single most frequently visited Web site listed was that of the Library of Congress; its American Memory Historical Collection was identified specifically seven times. Listservs, news-type services for historians, and individual publications such as the New York Times or the American Historical Review also were mentioned.

Historians have worked to acquire their expertise with electronic information. They have taught themselves and learned from librarians and colleagues; some have attended workshops. The myth of the younger generation teaching the older appears where historians are concerned to be just that, a myth. Only five percent report learning from their children.

When assessing the impact of electronic resources on their research, onequarter of the historians responding to the survey considered that electronic sources had had little impact on their research; one individual dismissed them as a time-waster. However, most were highly appreciative. Many offered a comment that was a variation on "I can't imagine researching without them." They stressed the speed of electronic sources, the greatly increased access to information, and the saving of time and money. As one put it, "I get to spend more time in my office and actually get work done!" Those who complained that they were not useful in their field look forward eagerly to a day when they will be. To a considerable degree, awareness of the potential of electronic resources has raised expectations. One individual, who did feel that they had had a great deal of impact on his or her research, pointed out that when you found a citation, you still had to go after it in the old-fashioned way.

Historians used the Internet in teaching cautiously. Almost all respondents allowed use of Web sites for student assignments, but almost two-thirds established some guidelines or limitations. The most frequently recommended site was that of the Library of Congress, primarily for its American Memory collection and the Handbook of Latin American Studies. The National Archives Web site and those of the New York Times and PBS also were named by more than one historian.

Electronic publications also were treated with caution. Only 10 percent subscribe to any journal online, and only six percent subscribe to an e-journal, that is, an electronic journal with no print counterpart. Doubts about the role of e-journals in scholarly communication prevailed; more than half considered it too early to judge their value, whereas 29 percent did not consider publication in them as authoritative as publication in a print journal. Of the six e-journals mentioned, three are published at universities. These results were similar to those in the Canadian survey of social scientists and humanists in $1999-2000 .{ }^{36}$ It is certainly true that leading scholars have rarely chosen to publish in them.

\section{Issues and Problems}

When asked in the follow-up questions about any information problem they had experienced in their present research, many historians responded with some version of inadequate access. Assorted difficulties included that their own library did not have a good newspaper collection, did not subscribe to crucial databases, and did not have needed older material because the university was only twenty years old. Electronic databases were criticized as shallow-better suited to 
undergraduates than scholarship - and for inadequate indexing terminology. They required expertise the respondents did not have to make full use of them. Foreign-language materials presented problems; they were absent from collections, absent from databases, and difficult to use. One historian deplored his or her inability to read a source; a Russian scholar described the transliteration of Russian as a "mess."

Other problems clustered around access to primary sources. Many found that to see the material they needed, they had to travel. Worse, they might be denied access to material needed for their research because of political or governmental restrictions.

When asked to describe an occasion when they had chosen not to seek information from a source (person, library, index, bibliography, Internet, etc.), even when they believed that information relevant to their research might be available from that source, few could recall any such experience. However, several mentioned that they had called a halt to research when they felt they had enough to write, even if other sources promised to yield additional information. Some had tailored their research topics to minimize travel. Quality was a consideration; one historian, skeptical of the value of the Internet, avoided it and others did not use information from historians they considered unreliable.

Relationships with librarians were mixed. Librarians may not be viewed as hod-carriers, as they were in 1970, but historians balanced praise, such as for an interlibrary loan office's success, with complaints about rudeness and a mechanistic, "scripted" approach to reference work. More serious are the problems arising from the difference in disciplinary culture. In 1984, Stephen K. Stoan analyzed the lack of understanding between teaching faculty and librarians: teaching faculty claimed that librarians did not understand research, and librarians accused faculty of not knowing how to use the library. In 1991, Stephen Lehmann and Patricia E. Renfro described a related contrast, characterizing humanists as primarily interested in content and librarians as primarily interested in process and technique. This divergence is now less acute, as the arrival of electronic databases has forced historians to be more interested in the means of access, but it has not completely disappeared. ${ }^{37}$

\section{Conclusions}

Comparing the results of this study with those of the 1981 Stieg study demonstrates that although much related to historians' information-seeking habits has changed, many things have remained the same. In research, informal means of locating information, especially references in the works of other scholars and book reviews, continue to be prominent. Browsing is still important. Print remains the principal format of the information used, although electronic databases are used extensively in the discovery of information, and books still dominate the discipline. This domination of print is even clearer in the citation analysis than in the survey results. It is still true to describe the physical library as the laboratory of the historian, a role that explains much of the heavy use of WorldCat. E-journals are used rarely; most historians are uncertain of their value and thus of their reliability as sources of information.

One important change that has taken place is that catalog and index use has grown and promises to continue to grow. The increased use of bibliographic sources has its roots in both need and availability. Need there has been as long as there has been historical scholarship; the great Dahlmann-Waitz bibliography of Ger- 
man historical writing was begun in 1830 , Writings on American History soon after American history began to be studied, at the beginning of the twentieth century. Use of such bibliographic tools, however, was limited, unless the scope of the tools coincided with the historian's specialty, as the Isis bibliography did with the interests of historians of science. The focus of research was on primary resources, which could not be identified through bibliographies and indexes, rather than on secondary materials. Now many bibliographic resources exist, immediately visible on the desktop of any scholar who connects to the library of the institution with which he or she is affiliated. These bibliographic sources are easy and convenient, and require a much smaller investment of time than going through comparable printed indexes. Concurrent with the improvement of the cost-benefit ratio of a bibliographic search, the need for such searches has grown, as scholarly writing in almost every field of history threatens to become overwhelming. At a time when being informed about the literature is more important than ever, historians find it increasingly difficult to keep up with the scholarship in their areas of specialization. ${ }^{38}$ The use of indexes and bibliographies is an obvious solution to the difficulties created by these circumstances.

How knowledgeable historians are about bibliographic databases, almost all of which are now in electronic format, is unclear, although the fact that they have enough understanding of the scope of databases to choose such relevant ones as are indicated in table 6 is a very positive sign. They use a wide range of databases, but this dispersion reflects the wide spread of the discipline. Only four databases were used by more than 10 percent.

Another area in which the evidence is unclear is that of historians' connectedness with their professional community. Historians traditionally have worked alone and multi-authored publications are rare; in this study, none of the five books analyzed in the 2001 citation analysis and only six of the ninety-five articles, or 6.3 percent, had more than one author. ${ }^{39}$ On the other hand, more than half found talking to colleagues an occasion when information was serendipitously discovered and a few identified talking to colleagues as their most frequent way of discovering information for their research. In addition, some participate in listservs.

In 1984, in an investigation that largely focused on historians, Hernon suggested that social scientists were suffering from information overload. In the intervening twenty years, the potential for contracting this indisposition has only increased exponentially. ${ }^{40}$ If those who participated in the survey are representative, however, historians themselves only rarely feel inundated by too much information. Out of the many comments, only three even hinted at such a feeling. Instead, the complaints were that a database did not go back far enough, that there was no appropriate database in the individual's field, that the database did not contain the full text of a document, that the library did not have a good enough newspaper collection, that a library did not subscribe to enough databases, or some other expression of a desire for more. One can only conclude that the fundamental problem of historical research, finding enough information about the problem under investigation to come to appropriate conclusions, remains, although the means of locating information have improved so much. Is it a case of the more they have, the more they want? Those collection development officers who think historians are insatiable may just be right.

Overall, the information needs of historians appear to be better served than 
they were a generation ago. Bibliographic sources have improved in quantity and in their fit with the needs of historians. They are easier to use. At the same time, historians have become more sophisticated about information sources. They have always understood their own information needs but now translate them more eas- ily into what the bibliographic universe offers. The near-universal accessibility to library catalogs and the availability of keyword searching in most electronic databases are greatly appreciated. In short, historians are well on their way to becoming the new user called for by the new technologies and new products. ${ }^{41}$

\section{Notes}

1. Lord Chesterfield to his son, February 5, 1750, in The Letters of Philip Dormer Stanhope, 4th Earl of Chesterfield, ed. Bonamy Dobrée (London: Eyre and Spottiswoode, 1932), v. 4, Letters: 1748-1751, 1501; John Cannon, "The Historian at Work," in The Historian at Work (London: George Allen \& Unwin, 1980), 2.

2. Jeffrey G. Barlow, "Historical Research and Electronic Evidence: Problems and Promises," in Writing, Teaching, and Researching History in the Electronic Age, ed. Dennis A. Trinkle (Armonk, N.Y.; London: M. E. Sharpe, 1998), 196; historian's quotation from Barbara C. Orbach, "The View from the Researcher's Desk: Historians' Perceptions of Research and Repositories," American Archivist 54 (winter 1991): 29; Ross Atkinson, "Humanities Scholarship and the Library," LRTS 39 (1995): 82.

3. U.S. Dept. of Labor. Bureau of Labor Statistics, Occupational Outlook Handbook, 2002-03 ed., available online at http://www.bls.gov/oco/ocos054.htm (accessed 2 September 2003), s.v. Social Scientists, Other. In the term "primary sources," primary is used in the sense of first in order of time or development. In the International Encyclopedia of Social and Behavioral Sciences, primary sources are described as the written material produced more or less contemporaneously with the object of research, ideally recorded by eyewitnesses, although practicing historians today use it, as does the Occupational Outlook Handbook, for any source of evidence that provides them with direct, unmediated information about the object of study. International Encyclopedia of Social and Behavioral Sciences, ed. Neil J. Smelser and Paul B. Bates (Amsterdam: Elsevier, 2001), s.v. "History: Theories and Methods," by C. Lorenz, v. 10, 6871.

4. Constance C. Gould, Information Needs in the Humanities: An Assessment (Stanford, Calif.: Research Libraries Group, 1988), 7-14; Helen R. Tibbo, Abstracting, Information Retrieval and the Humanities: Providing Access to Historical Literature (Chicago: ALA, 1993), 4-7.

5. Margaret F. Stieg, "The Information of [sic] Needs of Historians," College E Research Libraries 42 (1981): 549-60.

6. The years 2001 and 1975 were the target dates, but the prizes were not consistent in whether they were for books published in the year the prize was awarded or for one published in the preceding year. Some prizes were not awarded every year, but in alternate years. The prizes used to provide the books for analysis were the Herbert Baxter Adams prize in European history, ancient history to 1815; the George Louis Beer prize for European international history since 1895; the Albert J. Beveridge prize for the best book in English on the history of the United States, Latin America, or Canada from 1492 to the present; the Howard R. Marraro prize for Italian or Italian-United States history; and the Wesley-Logan prize for African diaspora history. In making the choices of books and journals to analyze, several factors were present besides the presumption of excellence: comparability (i.e., a prize was given both in 1975 and 2000), geographic diversity of subject, and difference in time period. Greater diversity of geographic subject would have been preferred, but prizes for non-U.S. and non-European history are of very recent vintage. The absence of publications by historians working in countries other than the United States was accepted because the survey was limited to those working inside the United States. Data sets included author, title, physical format, date of publication, language, whether the item was a primary or secondary source, and LC classification. For citations to journal articles, the title of the journal also was noted and for citations from manuscripts, the repository in which the manuscripts were located.

The 2001 prize books were (Adams) Malachi Haim Hacohen, Karl Popper-The Formative Years, 1902-1945 (Cambridge, Eng.: Cambridge Univ. Pr., 2000); (Beer) John Connelly, Captive University: The Sovietization of East German, Czech, and Polish Higher Education, 1945-1956 (Chapel Hill, N.C.: Univ. of North Carolina Pr., 2000); (Beveridge) Alexander Keyssar, The Right to Vote: The Contested History of Democracy in the United States (New York: Basic Books, 2000); (Marraro) 
Anthony Grafton, Cardano's Cosmos: The Worlds and Works of a Renaissance Astrologer (Cambridge, Mass.: Harvard Univ. Pr., 2000; and (Wesley-Logan) David Eltis, The Rise of African Slavery in the Americas (Cambridge, Eng.: Cambridge Univ. Pr., 1999). The journals used were the American Historical Review, the Journal of American History, the Journal of Modern History, the Journal of African History, and Past and Present; the volume of a journal, it should be noted, is not always identical with a calendar year. The books analyzed for 1975 were (Adams) James S. Donnelly, The Land and People of Nineteenth-century Cork (London, Boston: Routledge and Kegan Paul, 1975); (Beer) Charles S. Maier, Recasting Bourgeois Europe: Stabilization in France, Germany and Italy in the Decade after World War I (Princeton, N.J.: Princeton Univ. Pr., 1975); (Beveridge) David Brion Davis, The Problem of Slavery in the Age of Revolution, 1700-1823 (Ithaca, N.Y.: Cornell Univ. Pr., 1975); (Marraro) Robert Brentano, Rome before Avignon (New York: Basic Books, 1974). For the fifth 1975 book, Thomas S. Hines, Burnham of Chicago: Architect and Planner (Oxford Univ. Pr., 1974) was used. Hines's book was awarded the John H. Dunning prize in U.S. history, a prize that is awarded in alternate years. It was selected because the Wesley-Logan award only began in 1992. The same journals were used.

Fifty citations were randomly selected from each book and volume of a journal, a total of 250 book citations and 250 citations in journal articles for each of the two periods. The total population from which they were randomly selected was 5,541 citations in the 2001 books and 9,259 citations in the 2001 articles and in the 1975 books 5,099 citations and 6,232 citations in the 1975 articles. That yielded a total of 531 references from the 2001 books, 552 references from the 2001 articles, 584 references from the 1975 books, and 411 references from the 1975 articles.

7. Donald O. Case, Looking for Information: A Survey of Research on Information Seeking, Needs, and Behavior (Amsterdam: Academic Pr., 2002), xv, and especially chapters 10-12. Bibliographic essays on some aspect of information behavior appear regularly in the Annual Review of Information Science and Technology.

8. Peter Hernon, "Information Needs and Gathering Patterns of Academic Social Scientists, with Special Emphasis Given to Historians and Their Use of U.S. Government Publications," Government Information Quarterly 1 (1984): 401-29; Donald O. Case, "The Collection and Use of Information by Some American Historians: A Study of Motives and Methods, " Library Quarterly 61 (1991): 61-82; Charles Cole, "Information Acquisition in History Ph.D. Students: Inferencing and the Formation of Knowledge Structures," Library Quarterly 68 (1998): 33-54; Roberto Delgadillo and Beverly P. Lynch, "Future Historians: Their Quest for Information," College E Research Libraries 60 (May 1999): 245-59; Rebecca Green, "Locating Sources in Humanities Scholarship: The Efficacy of Following Bibliographic references," Library Quarterly 70 (2000): 201-29; Wendy M. Duff and Catherine A. Johnson, "Accidentally Found on Purpose: Information-seeking Behavior of Historians in Archives," Library Quarterly 72 (2002): 472-96.

9. Whether history belongs with the humanities or with the social sciences is an unresolved question. For the record, the authors of this study consider history to have more in common with the humanities, although they recognize that it draws frequently upon the social sciences for insights and methods. Tibbo summarizes the views in Abstracting, Information Retrieval and the Humanities, 3, suggesting that the operative factor in determining whether the historian pursues a humanistic or social scientific methodology is the type of history practiced. An excellent discussion of the issue can be found in the International Encyclopedia of the Social and Behavioral Sciences under "History and the Social Sciences."

10. Bath University Library, Investigation into Information Requirements of the Social Sciences (Research Report 1: Information Requirements of Researchers in the Social Sciences [June 1971]); Cynthia Corkill and Margaret Mann, Information Needs in the Humanities: Two Postal Surveys (Occasional Papers 2; British Library Research and Development Department Report, no. 5455) (Univ. of Sheffield: Centre for Research on User Studies, 1978); Sue Stone, "Humanities Scholars: Information Needs and Uses," Journal of Documentation 38 (1982): 292-313; Susan S. Guest, "The Use of Bibliographic Tools by Humanities Faculty at the State University of New York at Albany," Reference Librarian 18 (Summer 1987): 157-72; Stephen E. Wiberley Jr., "Habits of Humanists: Scholarly Behavior and New Information Technologies," Library Hi-Tech 9 (1991): 17-21; Rebecca Watson-Boone, "The Information Needs and Habits of Humanities Scholars," RQ 34 (1994): 203-16; Gould, Information Needs in the Humanities; Dimensions and Use of the Scholarly Information Environment, available online at http://www.clir.org/pubs/reports/reports/html.

11. Peter A. Uva, Information-Gathering Habits of Academic Historians: Report of the Pilot Study (Syracuse: State Univ. of New York, Upstate Medical Center, March 1977), ERIC ED 142483 ; Orbach, "The View from the Researcher's Desk," 32; Case, "The Collection and Use of Information by Some American Historians;" David Ellis, "Modeling the Information-Seeking Patterns of Academic Researchers: A Grounded Theory Approach," Library Quarterly 63 (1993): 469-86; Lokman I. Meho and Helen R. Tibbo, "Modeling the Information-seeking Behavior of Social Scientists: Ellis's Study Revisited," Journal of the American Society for Information Science and Tech- 
nology 54 (2003): 570-87; Clara M. Chu, "Literary Critics at Work and Their Information Needs: A Research-Phases Model," Library and Information Science Research 21 (1999): 247-73

12. Tibbo, Abstracting, Information Retrieval and the Humanities.

13. Arthur Monroe McAnally, "Characteristics of Materials Used in Research in United States History" (Ph.D. diss., Univ. of Chicago, 1951); Clyve Jones, Michael Chapman, and Pamela Carr Woods, "The Characteristics of the Literature Used by Historians," Journal of Librarianship 4 (1972): 137-56; M. Sara Lowe, "Reference Analysis of the American Historical Review," Collection Building 22 (2003): 13-20; Rebecca A. Jacob, "A Study in Interdisciplinarity in Citations to Journal Literature in the Journal of American History, 1960-1990" (MSLS thesis, Univ. of North Carolina, Chapel Hill, 1994); Edward A. Goedeken and Jean-Pierre V. M. Herubel, "Periodical Dispersion in American History: Observation on Article Bibliographies from the Journal of American History," Serials Librarian 27 (1995): 59-74; Eloise R. Hitchcock, "Materials Used in the Research of State History: A Citation Analysis of the 1986 Tennessee Historical Quarterly," Collection Building 10 (1989): 52-54; Katherine W. McCain, "Citation Patterns in the History of Technology," Library and Information Science Research 9 (Jan. 1987): 41-59; Jean-Pierre V. M. Herubel, "Materials Used in Historical Scholarship: A Limited Citation Analysis of the Journal of Garden History," Collection Management 14 (1991): 155-62.

14. Tibbo, Abstracting, Information Retrieval and the Humanities; Deborah Lines Andersen, "Academic Historians, Electronic Information Access Technologies, and the World Wide Web: A Longitudinal Study of Factors Affecting Use and Barriers to that Use," Journal of the Association for History and Computing 1 (1998), available online at http://mcel.pacificu.edu/history/jahcI1/ Anderson/Anderson.HTML (accessed 2 July 2003); _—_ "Historians on the Web: A Study of Academic Historians' Use of the World Wide Web for Teaching," Journal of the Association for History and Computing 3 (2000), available online at http://mcel.pacificu.edu/JAHC/JAHCIII2/ARTICLES/anderson/index.html (accessed 2 July 2003); Andersen and Dennis A. Trinkle, "“One or Two Is Not a Problem,' or, Technology in the Tenure, Promotion, and Review Process: A Survey of Current Practices in U.S. History Departments," Journal of the Association for History and Computing 4 (2001), available online at http://mcel.pacificu.edu/JAHC/JAHCIV1/ARTICLES/AndersonTrinkle/Anderson-Trinkle.html; Amy Schleigh, "At the Intersection of History and Technology: A Bibliography for Historians and Information Professionals," Journal of the Association for History and Computing 4 (November 2000), available online at http://mcel.pacificu.edu/JAHC/JAHCV3/ ARTICLES/Schleigh/Schleigh.html. [Accessed 8 November 2003]; Stephen Wiberley and William Goodrich Jones, "Patterns of Information Seeking in the Humanities," College E Research Libraries 50 (1989): 638-45; __ "Humanists Revisited: A Longitudinal Look at the Adoption of Information Technology," College \& Research Libraries 55 (1994): 499-509; _—_ "Time and Technology: A Decade-long Look at Humanists' Use of Electronic Information Technology," College E Research Libraries 61 (2000): 421-31; Marcia J. Bates, "The Getty End-user Online Searching Project in the Humanities: Report no. 6: Overview and Conclusions," College E Research Libraries 57 (1996): 514-23; Bates, Deborah N. Wilde, and Susan L. Siegfried, "Research Practices of Humanities Scholars in an Online Environment: The Getty Online Searching Project Report no. 3," Library and Information Science Research 17 (1995): 5-40;___ "A Profile of End-user Searching Behavior by Humanities Scholars: The Getty Online Searching Project Report no. 2," Journal of the American Society for Information Science 44 (1993): 273-91; ___ "An Analysis of Search Terminology Used by Humanities Scholars: The Getty Online Searching Project Report no. 1," Library Quarterly 63 (1993): 1-39.

15. Available online at http://www.ourfutureourpast.ca/e-pub/; Suzanne R. Graham, "Historians and Electronic Resources: A Citation Analysis," JAHC (Journal of the Association for History and Computing) 3 (Nov. 2000), available online at http://mcel.pacificu.edu/JAHC/JAHCIII3/WORKS/ Graham.html (accessed 8 November 2002); ___ "_Historians and Electronic Resources: A Second Citation Analysis," JAHC (Journal of the Association for History and Computing) 4 (Aug. 2001), available online at http://mcel.pacificu.edu/JAHC/JAHCIV2/ARTICLES/graham/graham.html (accessed 8 November 2002); _—_ "Historians and Electronic Resources: Patterns and Use," Journal of the Association for History and Computing 5 (Sept. 2002), available online at http://mcel. pacificu.edu/JAHC/JAHCV2/ARTICLES/graham/graham.html (accessed 8 November 2002); Joel D. Kitchens, "Electronic Publishing and the Future of History," available online at http://www2. h-net.msu.edu/ histbibl/kitchens.html; Marshall Poe, "Do We Need the UP? A New Model for Scholarly Publishing in History," Journal of the Association for History and Computing 4 (2001), available online at http://mcel.pacificu.edu/JAHC/JAHCIV2/ARTICLES/poe/poe.html; Carol Ann Hughes and Nancy L. Buchanan, "Use of Electronic Monographs in the Humanities and Social Sciences," Library Hi Tech 19 (2001): 368-75; Kate Wittenberg, "Digital Technology and Historical Scholarship: A Publishing Perspective," Journal of the Association for History and Computing 5 (2002), available online at http//mcel.pacificu.edu/JAHC/JAHCV3/ARTICLES/Wittenberg/wittenberg. html; Janice L. Reiff, "New Technologies and the Practice of History," Perspectives (1998); Mark 
S. Newmark, "A Call for a New Generation of Historical Web Sites," Journal of the Association for History and Computer 2 (November 1999), available online at http://mcel.pacificu.edu/jahc/jahcII3/ K12II3/newmark.html. [Accessed 8 November 2003]; Michael O'Malley and Roy Rosenzweig, "Brave New World or Blind Alley? American History on the World Wide Web," Journal of American History (1997); Nicholas Sarantakes, "So That a Tree May Live: What the World Wide Web Can and Cannot Do for Historians," Perspectives (1999), available online at http://www.theaha. org/perspectives/issues/1999/9902/9902COM3.CFM.

16. Stone, "Humanities Scholars," 292-95; Ron Blazek and Elizabeth Aversa, The Humanities: A Selective Guide to Information Sources, 5th ed. (Englewood, Colo.: Libraries Unlimited, 2000), 2, 4; Wiberley, "Habits of Humanists," 17.

17. Cf. Tibbo, Abstracting, Information Retrieval and the Humanities, 68-79.

18. References were categorized into primary or secondary using the commonly accepted definitions of primary sources as records and data created during the time period being studied or afterwards by individuals reflecting their involvement in the events of the time and secondary sources as works of analysis and interpretation that build on primary sources. Ultimately, such judgments are subjective and contextual; a history textbook, for example, may be a secondary source in one publication, but a primary source in a study of how history was taught in the 1950s.

19. Jones, Chapman, and Woods, "The Characteristics of the Literature Used by Historians," 141; Lowe, "Reference Analysis of the American Historical Review," 16.

20. Jones, Chapman, and Woods, "The Characteristics of the Literature Used by Historians," 151; Tibbo, Abstracting, Information Retrieval and the Humanities, 92.

21. Tibbo, Abstracting, Information Retrieval and the Humanities, 92-93.

22. Margaret F. Stieg, The Origin and Development of Scholarly Historical Periodicals (University, Ala.: Univ. of Alabama Pr., 1986), 88.

23. A 1997 conference sponsored jointly by the American Council of Learned Societies, Association of American University Presses, and Association of Research libraries addressed many of these issues. From the conference proceedings, The Specialized Scholarly Monograph in Crisis: Or How Can I Get Tenure If You Won't Publish My Book? ed. Mary M. Case (Washington, D.C.: Association of Research Libraries, 1999), see especially Stanley Chodorow, "The Once and Future Monograph," 11-17; Marlie Wasserman, "How Much Does It Cost to Publish a Monograph and Why?" 33-40; Peter Nathan, "Promotion: A Triple Whammy at Research Universities," 73-76; and Sanford G. Thatcher, "Thinking Systematically about the Crisis in Scholarly Communication," 85-94.

24. Nicholas J. Morgan and Richard H. Trainor, "Liberator or Libertine? The Computer in the History Classroom," in The Humanities and the Computer: New Directions (Oxford: Clarendon Pr; New York: Oxford Univ. Pr., 1990), 61; Tibbo, Abstracting, Information Retrieval and the Humanities, 130.

25. Lowe, "Reference Analysis of the American Historical Review," 15.

26. Tibbo, Abstracting, Information Retrieval and the Humanities, 92.

27. Ibid., $1-2$.

28. To be specific: AC, AP, BF, BL, BR, BX, CB, CT, D, DA, DB, DC, DD, DF, DK, DS, DT, E, F, G, GA, GF, GN, GV, H, HB, HC, HD, HE, HF, HG, HJ, HM, HN, HQ, HT, HV, HX, JA, JC, JF, JK, JL, JN, JQ, JS, JV, K, KF, KFI, KFN, KJP, LA, LB, LC, LF, ND, PA, PG, PL PN, PQ, PR, PS, PT, PZ, $\mathrm{Q}, \mathrm{S}, \mathrm{SB}, \mathrm{TT}, \mathrm{TX}, \mathrm{UH}, \mathrm{VB}, \mathrm{VK}, \mathrm{Z}$.

29. Historical research has several of the characteristics identified by Green as conditions in which footnote tracing is to be preferred to the use of indexes, the importance of primary sources, the spread of desired references over a long period of time, and a not particularly well-defined vocabulary with which to search bibliographic resources. Green, "Locating Sources in Humanities Scholarship," 226.

30. Tibbo, Abstracting, Information Retrieval and the Humanities, refers frequently to the use of browsing of library shelves by historians, e.g., pp. 1, 5-6, 118-19.

31. Barbara Tuchman's finding of the series of articles by Stilwell on the personalities of the civil war in the weekly newsletter of his unit in China while doing the research for her book Stilwell and the American Experience in China is a fairly well-known example. Daniel Liestman, "Chance in the Midst of Design: Approaches to Library Research Serendipity," RQ 31 (1992): 524.

32. Claire-Lise Bénaud and Sever Bordeianu, "Electronic Resources in the Humanities," Reference Services Review 23 (1995): 48; Wiberley and Jones, "Patterns of Information Seeking in the Humanities," 499; Delgadillo and Lynch, "Future Historians," 248.

33. A conversation with Barbara Dahlbach, former electronic services librarian at the University of Alabama, clarified these events.

34. Hernon, "Information Needs and Gathering Patterns of Academic Social Scientists, with Special Emphasis Given to Historians and Their Use of U.S. Government Publications," 403. 
35. See Tibbo, Abstracting, Information Retrieval and the Humanities, 139-41; Wiberley and Jones, "Patterns of Information Seeking in the Humanities;" Bates, Wilde, and Siegfried, "An Analysis of Search Terminology Used by Humanities Scholars."

36. Available online at http://www.ourfutureourpast.ca/e-pub/.

37. Walter Rundell Jr., In Pursuit of American History: Research and Training in the United States (Oklahoma: Univ. of Oklahoma Pr., 1970), 284; Stephen K. Stoan, “Research and Library Skills: An Analysis and Interpretation," College E Research Libraries 45 (Mar. 1984): 99; Stephen Lehmann and Patricia E. Renfro, "Humanists and Electronic Information Services: Acceptance and Resistance," College E Research Libraries 52 (1991): 409.

38. R. Stephen Humphreys, “Why Do We Write Stuff That Even Our Colleagues Don't Want to Read?" in The Specialized Scholarly Monograph in Crisis, Or How Can I Get Tenure If You Won't Publish My Book, ed. Mary M. Case (Washington, D.C.: Association of Research Libraries, 1999), 21; Nicholas J. Morgan and Richard H. Trainor, "Liberator or Libertine? The Computer in the History Classroom," in The Humanities and the Computer: New Directions (Oxford: Clarendon Pr., New York: Oxford Univ. Pr., 1990), 63-64.

39. Lowe, "Reference Analysis of the American Historical Review," 18-19. Five of the six articles with more than one author had two authors, one had three.

40. Hernon, "Information Needs and Gathering Patterns of Academic Social Scientists, with Special Emphasis Given to Historians and Their Use of U.S. Government Publications," 419; Peter Lyman and Hal R. Varian, "How Much Information," 2000, available online at http://www.sims. berkeley.edu/research/projects/how-much-info/ (accessed 6 October 2003).

41. David J. Staley, "From Writing to Associative Assemblages: 'History' in an Electronic Culture," in Writing, Teaching, and Researching History in the Electronic Age, ed. Dennis A. Trinkle (Armonk, N.Y.; London: M.E. Sharpe, 1998), 4. 


\section{APPENDIX A Survey on the Information Needs of Historians}

The Directory of American Scholars, History, was used as the source of the sample in the Stieg survey. Because the current edition of the directory is several years old, a more current source for the survey population was needed for this survey. The use of the history departments in universities that were in the doctoral/research universities-extensive Carnegie classification rather than the directory meant that independent historians, historians employed in archives, and historians teaching in colleges were not present in this survey. See http://www.carnegiefoundation.org/Classification/.

\section{Part A. Information Sources}

The following questions pertain to the types of materials that you use in your research

1. Please check all sources you consider to be important for your research.
$\square$ Journal articles
$\square$ Books
$\square$ Manuscripts, archives, and special collections
$\square$ Genealogical sources
$\square$ Newspapers
$\square$ Government documents
$\square$ Statistical sources
$\square$ Artifacts or museum pieces
$\square$ Oral interviews (either those you have conducted or those conducted by other scholars)
$\square$ Audio/visual materials
$\square$ Maps
Photographs
$\square$ Dissertations
$\square$ Conference Proceedings
$\square$ Publications of scholarly organizations
$\square$ Web sites

2. Please list any other materials you consider to be important for your research.

3. 1 Which of the above materials do you use most frequently as a source of primary information?

4. 1 Which of the above materials do you use most frequently as a source of secondary information?

5. How often do you use microfiche/ microfilm?
$\square$ Frequently
$\square$ Sometimes
$\square$ Never

6. Do you use sources in languages other than English?

$\square$ I use many sources in languages other than English.

$\square$ I seldom use sources in languages other than English.

$\square$ I do not use any sources in languages other than English.

7. How do you deal with sources in foreign languages?

$\square$ I read the source. $\square$ I try to get a translation.

$\square$ I search for a summary or abstract of the source. $\quad \square$ I ignore the source.

8. 1 Is secondary literature more important, less important, or of approximately the same importance in your research now as it was when you wrote your first postdissertation scholarly publication?

$\square$ Secondary literature is more important now.

$\square$ Secondary literature is less important now.

$\square$ Secondary literature is equally important now.

9. Which is more important to you as a source of secondary information, books or journals?
$\square$ Books
$\square$ Journals
$\square$ They are equally important.
Not sure

\section{Part B. Methods of Discovering Relevant Information}

1. Please check all of the ways you discover information for research.

$\square$ Abstracts, indexes, or bibliographic databases (e.g., Historical Abstracts, New York Times Index, Academic Search Elite)

$\square$ Discussion with colleagues at your institution

$\square$ Consulting experts at other institutions

$\square$ Library catalogs at other institutions 
$\square$ National bibliographic databases (e.g., RLIN, WorldCat)

$\square$ Archival finding aids $\square$ Browsing the stacks in a library

$\square$ By accident (e.g., while going through the manuscripts of an individual you discover valuable information on a completely different individual whom you are also investigating)

$\square$ Book reviews $\square$ Publisher catalogs

$\square$ Specialized bibliographies (e.g., The War of the American Revolution: A Selected Annotated Bibliography of Published Sources)

$\square$ Web sites other than those relevant to the published sales of books and journals

$\square$ Web sites of bookstores or distributors of books (e.g., Amazon.com, Schoenhof's Foreign Books, Harvard University Press)

$\square$ In used bookstores $\square$ In commercial bookstores

$\square$ Through listservs, Internet forums, or newsgroups

$\square$ Reference librarians in a non-archival academic or public institution (e.g., your institution's main library, the Library of Congress)

$\square$ Archivists or reference librarians in a special collections library or archive

$\square$ Government databases, government Web sites, or printed government guides, handbooks, or bibliographies (e.g., GPO Access, The Monthly Catalog)

2. Please list any other ways you have discovered information for your research.

3. 1 Which is the most frequent way you discover primary source information for your research?

4. Which is the most frequent way you discover secondary information for your research?

5. Which abstracting services, indexes, and specialized or history-related bibliographies do you most often use to locate secondary literature?

6. 1 Many indexes and abstracts are published in print and electronic form. Which do you prefer?
$\square$ Print
$\square$ Electronic (e.g., Internet, CD-ROM)
$\square$ I have no preference.

7. How often does serendipity play a role in your discovery of new information? Serendipity is the unintentional discovery of valuable information (by chance or luck). For example, while working on one topic of research, you come across valuable information for an entirely different topic that you also investigating.

$\square$ Frequently $\square$ Occasionally $\square$ Never

8. When does serendipity often occur? Please check all answers that apply.

$\square$ Browsing the stacks in a library $\square$ While talking to colleagues or other scholars

$\square$ Browsing the Internet $\quad \square$ While searching for articles in an online database

$\square$ While doing a search in an online library catalog

$\square$ While reading works, book reviews, or other publications

$\square$ While browsing a collection in an archive or special collections library

$\square$ While reading messages on a listserv or online discussion forum

\section{Part C. Electronic Sources}

1. Which databases do you use most often (e.g., Project Muse, America: History and Life, the Avalon Project)?

2. How do you access these databases? Please check all answers that apply.

$\square$ Through your institution's library $\square$ Through your department

$\square$ Through a personal subscription $\square$ The database is freely accessible from a Web site

$\square$ Other

3. When I do a search in a bibliographic database, I prefer:

$\square$ Relevance (retrieval of a few records, all of them relevant to my topic, but with the chance that many other works might fall through the cracks, due to the limiting parameters of this type of search) 
$\square$ Depth (retrieval of the largest number of records which might pertain to my topic and in which I must spend time filtering out irrelevant citations)

4. 1 When a search in a bibliographic database yields too many hits: (Check all answers that apply.)

$\square$ I start over.

$\square$ I try to choose those citations from the most respected journals in the profession.

$\square$ I choose the most current citations.

$\square$ I go through all records retrieved not wanting any citations to fall though the cracks.

$\square$ I think of new terminology to use in my search.

$\square$ I look for another database from which to do the same search.

$\square$ I ask a librarian to show me how to perform an effective search in that particular database.

5. Please describe any problems you have encountered using databases.

6. How often do you use the Internet at home for professional purposes?

$\square$ Frequently $\square$ Occasionally $\square$ Never

$\square$ I do not have access to the Internet from home.

7. Do you personally subscribe to any journals online?

$\square$ Yes $\quad \square$ No

8. Do you subscribe to any E-journals? E-journals are journals that have no print counterpart and have been created solely for online.

$\square$ Yes $\quad \square$ No

9. If you answered yes to question 8 , which titles do you subscribe to?

10. Electronic journals are a new form of scholarly communication.

$\square$ I consider a publication in an e-journal to be as authoritative as a publication in a print journal.

$\square$ I do not consider publication in an e-journal to be as authoritative as publication in a print journal.

$\square$ It is too soon to judge their relative value.

11. How useful have electronic sources been in helping you to locate primary sources?
$\square$ Very Helpful
Sometimes helpful
$\square$ Rarely helpful
$\square$ I do not use electronic sources to locate primary information.

12. How helpful have electronic sources been in helping you to locate secondary sources?
$\square$ Very Helpful
Sometimes helpful
$\square$ Rarely helpful

$\square$ I do not use electronic sources to locate secondary information.

13. Some manuscripts and other primary source materials, such as images, have been digitized and are accessible online.

$\square$ I use them frequently. $\quad \square$ I sometimes use them.

$\square$ I rarely use them. $\quad \square$ I never use them.

14. If you used the digitized version of a manuscript, would you still feel it necessary to look at the original in order to use it in your research?
$\square$ Yes
$\square$ No
$\square$ Not sure

15. Which Web sites do you most frequently use?

16. How have you learned to use electronic sources? Please check all answers that apply.

$\square$ I taught myself.

$\square$ I learned from my colleagues.

$\square$ I learned from a librarian.

$\square$ I had some type of instruction from a class or workshop.

$\square$ I learned from my children.

$\square \quad$ I learned from a database provider (e.g., EBSCO). 
$\square$ I learned from other individuals not listed in these choices.

$\square$ I have not learned how to use electronic sources

$\square$ I do not use electronic sources.

$\square$ I would like more instruction in how to use electronic sources.

17. What impact have electronic sources had on your research?

\section{Part D. Teaching.}

The following questions relate to your information practices as a teacher.

1. Please check all of the following responses that best describe your policy on student use of Web sites for class assignments.

$\square$ I have no policy.

$\square$ I do not consider Web sites appropriate sources of information for class assignments.

$\square$ Student use of Web sites is encouraged.

$\square$ Student use of Web sites is allowed, but only as a supplement to books and journals.

$\square$ Students are allowed to use Web sites according to guidelines I have created.

2. Do you incorporate Web sites into your classroom instruction?

$\square$ Yes $\quad \square$ No

3. Which Web sites do you recommend to your students?

4. Which sources do your students use most for their written assignments?

$\square$ Special collections or archival materials $\square$ Newspapers

$\square$ Books $\square$ Journal articles $\quad \square$ Audiovisual media

$\square$ Maps $\square$ Government documents $\square$ Web sites

\section{Part E. Professional Information}

1. The university or institution with which you are affiliated:

2. Number of years teaching at the post-secondary level.
$\square$ 1-5
$\square$ 6-10
11-15
$\square$ 16-20
$\square$ 21-25

3. Your rank.
$\square$ Professor
Associate Professor
Assistant Professor
Instructor
$\square$ Lecturer
$\square$ Adjunct (any rank)
$\square$ Other

4. Your area(s) of research.

5. Your age.
$\square$ 20-29
$30-39$
$40-49$
$50-59$
$\square$ 60-69 $\square 70+$

6. Your gender.

$\square$ Female

$\square$ Male

7. Would you be willing to be interviewed by telephone as a follow-up to this survey? If the answer is yes, please leave an e-mail, phone, or address below so that we may contact you if we need to.

Thank you for taking the time to participate in this study. 


\section{APPENDIX B \\ Seven Open-ended Questions}

1. Which of the following factors most frequently affect your choice of information sources: quality, availability, ease of use? Why? Are there times when one factors is more important than the others?

2. How would you define "quality" in an information source?

3. When searching for information on a topic in a bibliographic database such as WorldCat or Historical Abstracts or America, History and Life, which kind of search are you most likely to do, a subject heading search or a keyword search?

4. If you come up with 100 titles from a subject search in WorldCat or a bibliographic database such as Historical Abstracts or America, History and Life, on what basis do you distinguish which ones you will try to obtain and which ones aren't as promising?

5. Please describe any problems you have experienced with bibliographic databases such as WorldCat or Historical Abstracts or America, History and Life.

6. Can you recall any instance when you avoided or consciously chose not to seek information from a source (person, library, index, bibliography, Internet, etc.) even if you believed that information relevant to your research might be available from that source? Please describe the situation.

7. If serendipity or browsing is a part of your research process, could you give an example in which it played an important role? 